\title{
15
}

\section{Energy and environment in China}

\author{
Kejun Jiang and Xiulian Hu
}

\section{Energy use in China}

Due to rapid economic growth, China's total primary energy consumption increased from 400 mega-tonnes of oil equivalent (Mtoe) in 1978 to nearly 1,820 Mtoe in 2007, with an annual average rate of increase of 5.3 per cent (Figure 15.1) (NBS 2006a, 2006b, 2007a). Coal is the major energy source, providing 70.7 per cent of total primary energy use in 1978 and 71 per cent in 2006 (Figure 15.2). There has been a dramatic surge in recent years in the rate of increase of energy use in China, as well as widespread energy shortages.

China's energy development strategy gives high priority to conservation and improvements in energy efficiency, as well as to the efficient and clean use of coal and other fossil-fuel energy sources. The objective of developing clean-coal technology is to improve the efficiency of coal utilisation, reduce environmental pollution and promote economic development. High efficiency and clean technology will be crucial for China to achieve a low-emission development path.

Energy-efficiency improvements in the steel-making industry have been driven by the diffusion of advanced technology (Figure 15.3). Despite these improvements, steel making in China remains about 20 per cent less efficient than in Japan.

To realise China's sustainable development, the national energy development strategy includes a policy of energy conservation prioritisation, as well as vigorously developing renewable energy and new energies in China. 


\section{Figure 15.1 Energy production and consumption in China, 1960-2007}

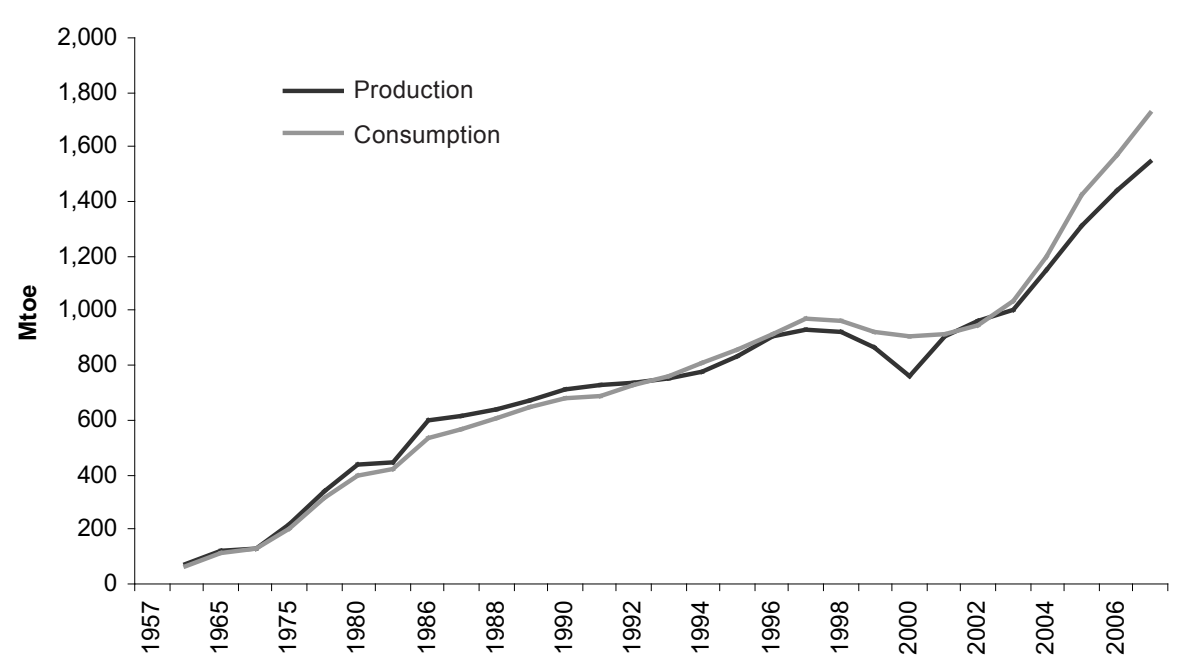

Source: National Bureau of Statistics (NBS), 2007b. China Statistical Yearbook 2007, China Statistics Press, Beijing.

Figure 15.2 Primary energy use in China by energy type, 1957-2006

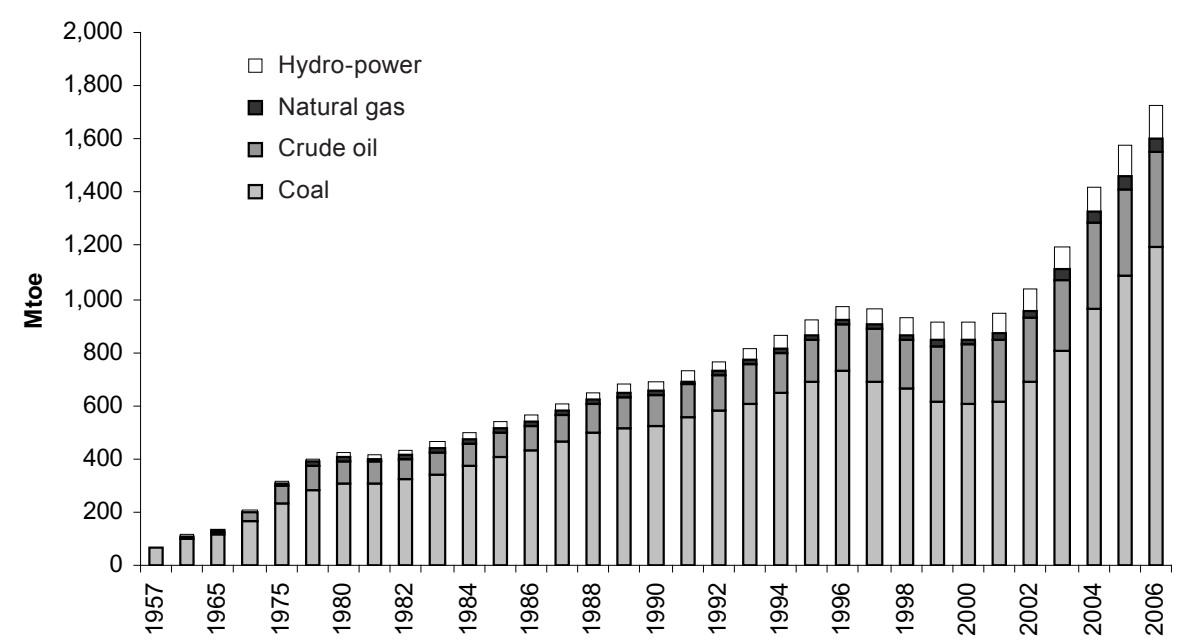

Source: National Bureau of Statistics (NBS), 2007b. China Statistical Yearbook 2007, China Statistics Press, Beijing. 


\section{Figure 15.3 Introduction of energy-efficiency improvements in steel making in China, 1970-2000}

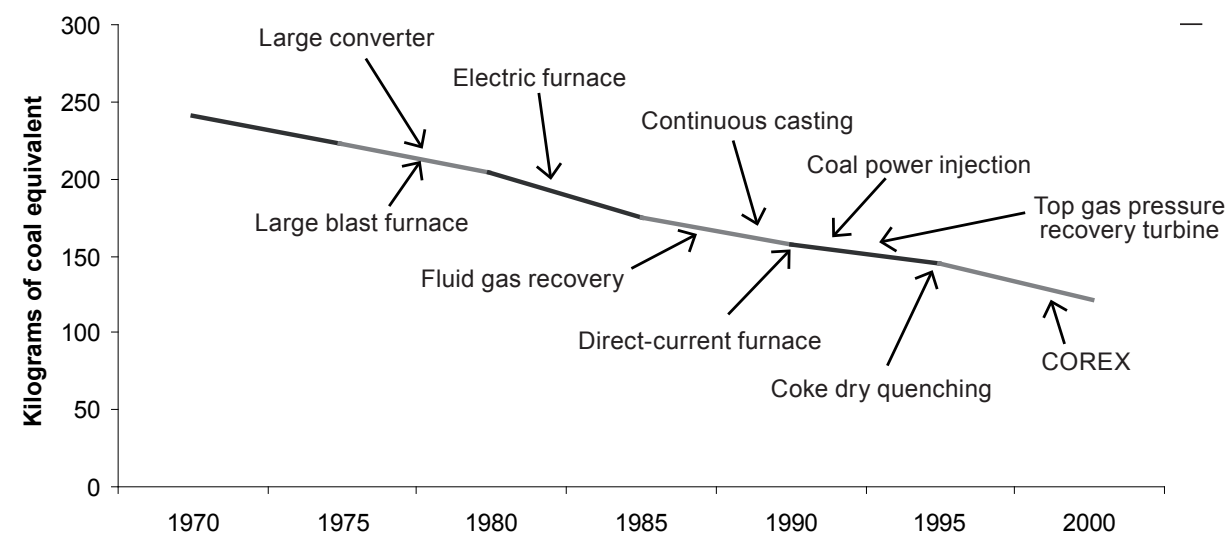

Source: Jiang, K., Morita, T., Masui, T. and Matsuoka, Y., 2006. 'Global long-term GHG mitigation emission scenarios based on AIM', Environment Economics and Policy Studies, 3.

Figure 15.4 Energy-efficiency improvement in China, 1960-2006

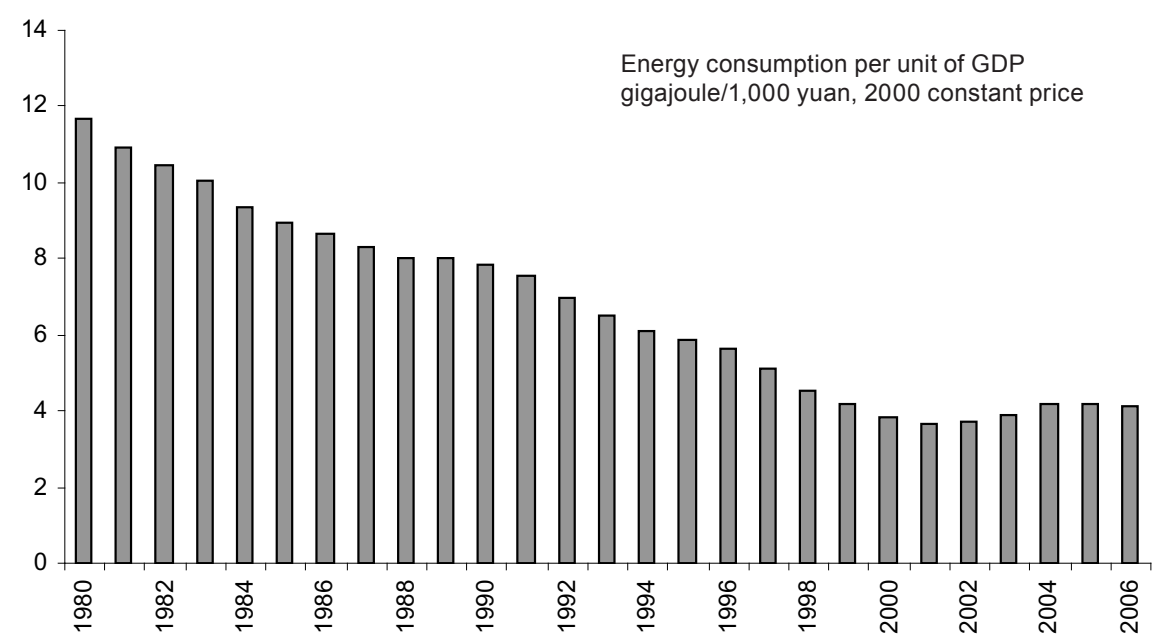

Source: Calculated by the authors based on data from National Bureau of Statistics (NBS), 2007b. China Statistical Yearbook 2007, China Statistics Press, Beijing. 
China has implemented a series of economic and technological policies for energy conservation and has also established a three-tier system of energy saving within the central government, local governments and industry and enterprises since the 1980s. The 1998 Energy Conservation Law further established the energy-management system. China has implemented a series of energy-saving technological policies, including starting a national 'Energy Conservation Propaganda Week', energy-efficiency standards, a marking and authentication system, and is effectively advancing energy-saving practices and improving energy efficiency.

To promote the application of new and renewable energies in the long term, China has given financial subsidies and support to technical development. It also provides discount loans for the development and use of small hydropower and wind-power plants, in addition to implementing tax preferences and protective price policies. With the implementation of these measures, the energy-consumption structure is being constantly optimised and the quality of energy supply has improved. The rapid development of clean energies and the growth of the proportion of high-quality energy in the total play an important role in enhancing energy efficiency and improving atmospheric quality.

As a result, energy efficiency improved significantly after 1980. From 1980 to 2000 , the annual average energy improvement rate was 5.4 per cent (Figure 15.4). Due to the rapid development of industry in China after 2000, however, especially of energy-intensive products, improvements in energy efficiency with regard to gross domestic product (GDP) were negative.

\section{Energy supply in China}

Since the period of reform and 'opening-up', the energy industry has achieved rapid growth, contributing to the sustainable development of the national economy. China has set up an energy-supply framework that gives priority to coal and focuses on electricity generation and the development of renewable energy. It has built an integrated energy-supply system; there are many large coal-mines with an output capacity of more then 10 million tonnes and petroleum-producing bases have been set up in Daqing, Shengli, Liaohe and Talimu. At the same time, gas production has increased rapidly, the proportion of commercialised renewable resources in the primary energy structure has improved, and remarkable progress has been made in electricity generation.

In 2004, China replaced Russia as the second-biggest energy producing country in the world. In 2006, primary energy output was 2,201.56 mega-tonnes of coal equivalent (Mtce) - an increase of 251 per cent from 1978. Coal output was up to 2,373 Mt, maintaining China's first-place ranking in the world; gas 
output reached 58.55 billion cubic metres; and oil output was $185 \mathrm{Mt}$, while power generation was 2,865.7 terrawatt hours (TWh) - both of which ranked second in the world.

Due to the nature of China's energy-resource reserves, coal has long accounted for a large proportion of primary energy - up to 70 per cent-and, since 2001, the proportion has increased steadily, to 76.7 per cent in 2006 . The elasticity coefficient for electric power became more than 1 after 2000.

Tables 15.1 and 15.2 show energy output by fuel from 1990 to 2006, the rank of Chinese energy output, and the gross and structure of Chinese energy production from 1978 to 2006.

After 2003, China became a net importer of oil, and, by 2007, a net importer of energy. At present, China is the third-largest oil importer in the world. In 2006, China imported 145.18 Mt of crude oil and 46.01 Mt of petroleum products, while it exported 6.34 Mt of crude oil and 15.51 Mt of petroleum products; therefore, net crude oil imports were 138.84 Mt and net imports of petroleum products were $30.5 \mathrm{Mt}$. In 2006, the volume of imports of crude oil and oil products was worth US\$68 billion, accounting for 7.02 per cent of China's total volume of

\section{Table 15.1 Chinese energy output by fuel, 1990-2006}

\begin{tabular}{cccccc}
\hline Year & $\begin{array}{c}\text { Raw coal } \\
(\mathrm{Mt})\end{array}$ & $\begin{array}{c}\text { Crude oil } \\
(\mathrm{Mt})\end{array}$ & $\begin{array}{c}\text { Gas (hundred } \\
\left.\text { million } \mathrm{m}^{3}\right)\end{array}$ & $\begin{array}{c}\text { Electric power } \\
(\text { TWh })\end{array}$ & $\begin{array}{c}\text { Hydro-power } \\
(\text { TWh) }\end{array}$ \\
1990 & 1,080 & 138.3 & 153.0 & 621.2 & 126.7 \\
1991 & 1,087 & 141.0 & 160.7 & 677.5 & 124.7 \\
1992 & 1,116 & 142.1 & 157.9 & 753.9 & 130.7 \\
1993 & 1,150 & 145.2 & 167.7 & 839.5 & 151.8 \\
1994 & 1,240 & 146.1 & 175.6 & 928.1 & 167.4 \\
1995 & 1,361 & 150.1 & 179.5 & $1,007.0$ & 190.6 \\
1996 & 1,397 & 157.3 & 201.1 & $1,081.3$ & 188.0 \\
1997 & 1,373 & 160.7 & 227.0 & $1,135.6$ & 196.0 \\
1998 & 1,250 & 161.0 & 232.8 & $1,167.0$ & 198.9 \\
1999 & 1,280 & 160.0 & 252.0 & $1,239.3$ & 196.6 \\
2000 & 1,299 & 163.0 & 272.0 & $1,355.6$ & 222.4 \\
2001 & 1,381 & 164.0 & 303.3 & $1,480.8$ & 277.4 \\
2002 & 1,455 & 167.0 & 326.6 & $1,654.0$ & 288.0 \\
2003 & 1,722 & 169.6 & 350.2 & $1,910.6$ & 283.7 \\
2004 & 1,992 & 175.87 & 414.6 & $2,203.3$ & 353.5 \\
2005 & 2,205 & 181.35 & 493.2 & $2,500.3$ & 397.0 \\
2006 & 2,373 & 184.77 & 585.5 & $2,865.7$ & 435.8 \\
& & & & & \\
\hline
\end{tabular}

Source: National Bureau of Statistics (NBS), 2007b. China Statistical Yearbook 2007, China Statistics Press, Beijing. 


\section{Table 15.2 Gross and structure of Chinese energy production, 1978-2006}

$\begin{array}{cccccc}\text { Year } & \begin{array}{c}\text { Gross output } \\ (10,000 \text { tonnes } \\ \text { of standard coal) }\end{array} & \text { Raw coal } & \text { Proportion of energy production (\%) } \\ \text { Crude oil } & \text { Gas } & \begin{array}{r}\text { Hydro-power, nuclear } \\ \text { power, wind power }\end{array} \\ 1978 & 62,770 & 70.3 & 23.7 & 2.9 & 3.1 \\ 1980 & 63,735 & 69.4 & 23.8 & 3.0 & 3.8 \\ 1990 & 103,922 & 74.2 & 19.0 & 2.0 & 4.8 \\ 1995 & 129,034 & 75.3 & 16.6 & 1.9 & 6.2 \\ 2000 & 128,978 & 72.0 & 18.1 & 2.8 & 7.2 \\ 2001 & 137,445 & 71.8 & 17.0 & 2.9 & 8.2 \\ 2002 & 143,810 & 72.3 & 16.6 & 3.0 & 8.1 \\ 2003 & 163,842 & 75.1 & 14.8 & 2.8 & 7.3 \\ 2004 & 187,341 & 76.0 & 13.4 & 2.9 & 7.7 \\ 2005 & 206,068 & 76.5 & 12.6 & 3.2 & 7.7 \\ 2006 & 221,056 & 76.7 & 11.9 & 3.5 & 7.9\end{array}$

Source: National Bureau of Statistics (NBS), 2007b. China Statistical Yearbook 2007, China Statistics Press, Beijing.

imports, while the volume of exports of crude oil and oil products was worth US $\$ 17.48$ billion, accounting for 2.21 per cent of China's total volume of exports. Since 2001, China has imported much more coal than ever before-up to 38.25 Mt in 2006, which was 20 times more than in 2000.

\section{Energy and environmental development}

Coal is the main energy source in China, and the coal-based energy structure will be difficult to change in the long term. The relatively backward modes of coal production and consumption have increased the pressure for environmental protection. Coal consumption is the main reason for China's air pollution and is the main source of the country's greenhouse gas emissions. With the constant increase of motor vehicles in China, air pollution in some cities has become a combination of soot and vehicle exhausts.

The main pollutant emissions

Pollution emissions from energy production in China. The impact of energy production on the environment is manifested in the dust pollution and gas emissions from coal-mining and processing, and atmospheric pollution from the spontaneous combustion of coal gangue. According to data from the China 
Statistical Yearbook 2007 (NBS 2007b), China's coal-mining and washing industry in 2006 emitted 145,000 tonnes of sulphur dioxide, 122,000 tonnes of smoke and 176,000 tonnes of industrial dust, with removal rates of 38 per cent (sulphur dioxide), 88 per cent (smoke) and 40 per cent (industrial dust). In addition, in 2006, coal-mining and processing emitted 5 billion cubic metres of methane and 2.3 billion cubic metres of mine water, with mine-water utilisation of less than 40 per cent. In 2006, there were more than 1,600 waste dumps containing $4,200 \mathrm{Mt}$ of coal gangue, covering 17,000 hectares. More than 700,000 hectares have been lost to land collapse caused by mining.

The other major atmospheric pollutants in the energy-production process are sulphur dioxide, nitrogen oxides and soot from thermal power plants. Because of the rapid increase in coal consumption in recent years, China's thermal power industry uses mostly unwashed steam coal, making the power industry the main source of air pollution. According to the China Environmental Yearbook 2007 (SEPA 2007), in 2006, the thermal power industry emitted 12.041 Mt of sulphur dioxide (59 per cent of the total for China), 3.467 Mt of soot and 14,000 tonnes of industrial dust.

Pollutant emissions from energy consumption in China. The high growth of energy consumption in the industrial sector is still the main source of emissions of sulphur dioxide. In 2006, the industrial sector emitted $10.18 \mathrm{Mt}$ of sulphur dioxide, 18 per cent of which came from the production of non-metallic mineral products, 15 per cent from ferrous and non-ferrous metal smelting and processing and 11 per cent from the chemical industry.

The main coal-consuming provinces are Shandong, Hebei, Shanxi and Jiangsu, and other high-sulphur coal-consuming provinces are Guizhou, Sichuan and Chongqing in the southwest, which are the leading provinces for sulphur dioxide emissions.

China's State Environmental Protection Administration (SEPA) monitored 522 cities in 2005: 77.4 per cent of the cities had an average annual concentration of sulphur dioxide at 'Standard II' (0.06 milligrams per cubic metre), while 6.5 per cent were above Standard III ( 0.10 milligrams per cubic metre). The cities with the highest levels of sulphur dioxide pollution were distributed mainly in the provinces, autonomous regions and municipalities of Shanxi, Hebei, Gansu, Inner Mongolia, Yunnan, Guangxi, Hubei, Shaanxi, Henan, Hunan, Sichuan, Liaoning and Chongqing. In addition, based on comparisons of coal consumption and urban air quality in key cities, the cities with the lowest sulphur dioxide concentrations and best urban environmental quality were Haikou, Sanya, Zhaoqing, Beihai, Zhanjiang and Zhuhai-all of which had low levels of coal consumption and a good-quality energy structure. 
Emissions of nitrogen oxides and energy activities are closely related. The main sources for the emission of these gases are power-generation boilers, industrial boilers and kilns using natural gas, coal and heavy oil as their main fuel source, as well as the production of nitric acid, nitrogen fertiliser and explosives and vehicle exhausts. As there are a variety of factors related to nitrogen oxides emission and combustion processes, such as the technological level of the production process, it is difficult for SEPA to monitor these emissions, and there are no accurate data among the environmental statistics for the emissions of nitrogen oxides. According to a preliminary estimate, in 2006, China emitted a total of about $14 \mathrm{Mt}$ of nitrogen oxides-an increase of 8.5 per cent compared with 2000 . In the total amount of nitrogen oxides, thermal power accounted for 40 per cent and industrial boilers and kilns, chemical production processes and vehicle exhausts made up the remainder.

In 2006, the main sources of industrial dust emissions in China were as follows: thermal power, 45 per cent; non-metallic mineral production, 18 per cent; ferrous and non-ferrous metals smelting and pressing, 15 per cent; chemical raw materials and chemical production, 10 per cent.

In 2005, monitoring of acid rain was carried out in 696 Chinese cities. Acid rain was recorded in 357 cities, with the average annual rainfall $\mathrm{pH}$ value in the range of $3.87-8.35$, accounting for 51.3 per cent of city statistics. The cities with an average annual rainfall $\mathrm{pH}$ value of less than 5.6 accounted for 38.4 per cent, with an increase of 1.8 per cent compared with 2004. The proportion of cities with an average annual rainfall $\mathrm{pH}$ value of 5.6 or less increased by 0.7 per cent, while the proportion of cities with a $\mathrm{pH}$ value of less than 4.5 increased by 1.9 per cent. The cities with frequency of acid rain over 80 per cent have increased by 2.8 per cent. The cities with low $\mathrm{pH}$ value of the average annual precipitation and a higher frequency of acid rain than that of 2004 shows that China's acid rain pollution became more serious in 2005. Table 15.3 shows the major pollution emissions in China from 1995 to 2006.

\section{Greenhouse gas emissions}

The rapid increase of energy use in China has caused large quantities of carbon dioxide emissions. Figure 15.5 presents recent carbon dioxide emissions in China. China is now the world's second-largest emitter of greenhouse gases, after the United States. It is believed that, if there is no change in the trend of increasing energy use, China's carbon dioxide emissions will overtake those of the United States in the near future-making China the largest emitter in the world. 


\section{Table 15.3 Major pollution emissions in China, 1995-2006}

\begin{tabular}{lcccccc}
\hline Year & $\begin{array}{c}\text { Sulphur } \\
\text { dioxide (Mt) }\end{array}$ & Dust (Mt) & $\begin{array}{c}\text { Industrial } \\
\text { dust (Mt) }\end{array}$ & $\begin{array}{c}\text { Waste } \\
\text { water }(100 \\
\left.\text { million } \mathrm{m}^{3}\right)\end{array}$ & $\begin{array}{c}\text { Chemical } \\
\text { oxygen } \\
\text { demand (Mt) }\end{array}$ & $\begin{array}{c}\text { Industrial } \\
\text { solid waste } \\
(\mathrm{Mt})\end{array}$ \\
1995 & 23.70 & 17.44 & 17.31 & 415.3 &.. & 22.27 \\
2000 & 19.95 & 11.65 & 10.92 & 415.2 & 14.45 & 31.86 \\
2001 & 19.48 & 10.70 & 9.91 & 432.9 & 14.05 & 28.94 \\
2002 & 19.27 & 10.13 & 9.41 & 439.5 & 13.67 & 26.35 \\
2003 & 21.59 & 10.48 & 10.21 & 460.0 & 13.34 & 19.41 \\
2004 & 22.55 & 10.95 & 9.05 & 482.4 & 13.39 & 17.62 \\
2005 & 25.49 & 11.82 & 9.11 & 523.0 & 14.14 & 16.55 \\
2006 & 25.89 & 10.89 & 8.08 & 536.8 & 14.28 & 13.02 \\
\hline
\end{tabular}

Source: State Environmental Protection Administration (SEPA), 2007. China Environmental Year Book 2007, China Environmental Yearbook Press, Beijing.

\section{Figure 15.5 Carbon dioxide emissions in China, 1990-2006}

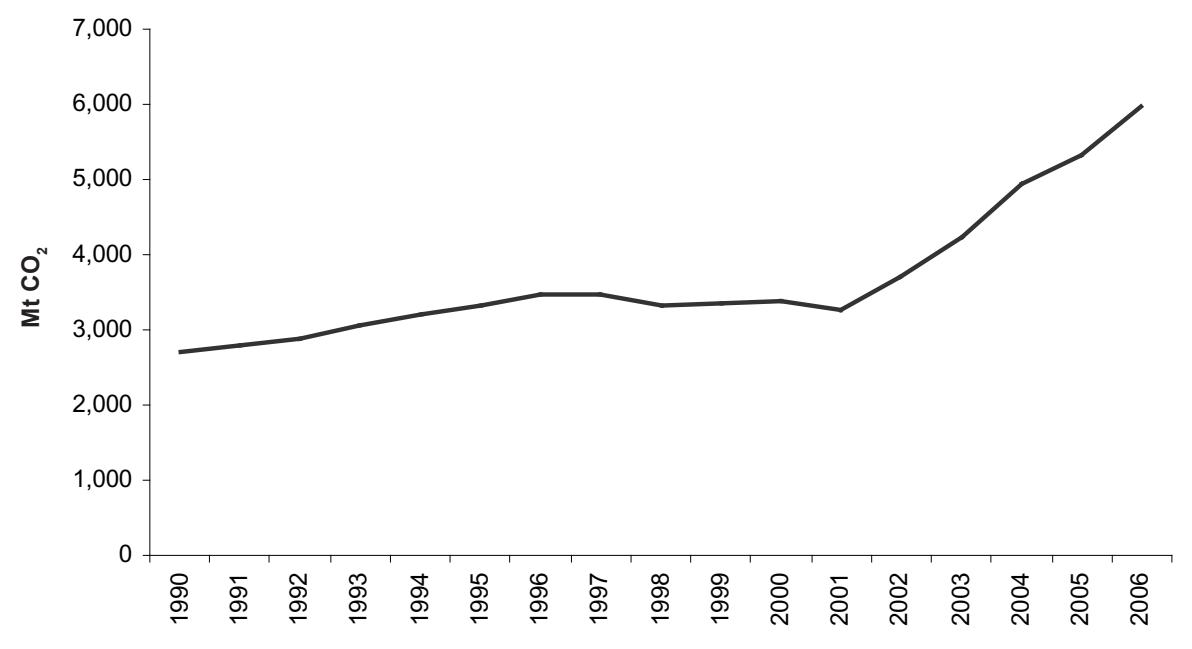

Source: State Environmental Protection Administration (SEPA), 2007. China Environmental Year Book 2007, China Environmental Yearbook Press, Beijing. 
China's massive exploitation of fossil fuels has resulted in a rapid increase in emissions of methane, which is the second most important greenhouse gas after carbon dioxide. Natural processes and human activities can generate methane emissions. The main human-made sources of methane include rice cultivation, cattle and sheep breeding, decomposing garbage in landfill, and coal-mining, gas and oil extraction, processing and transportation. Global annual methane emissions caused by animal intestinal fermentation are 60-100 Mt, accounting for 22 per cent of the anthropogenic total; methane emissions from animal dung amount to 20-30 Mt, accounting for 5.5-8 per cent of the anthropogenic total. China is the leading country for animal breeding, and animal enteric fermentation and animal dung are China's largest sources of methane emissions. China's rice plantations account for about 21 per cent of the global total, and rice growing is one of the main sources of methane emissions.

China is the world's largest coal-mining country, most of which is underground mining, accounting for 95 per cent of the total coal production. Coalmining is the key source of energy production-related methane emissions. According to the China Climate Change Initial National Communication submitted in 2004 by the Chinese government to the UN Framework Convention on Climate Change conference, in 1994, China's methane emissions were about 34.29 Mt-9.37 Mt (27 per cent) of which were caused by energy-generation activities. With the rapid increase in China's coal and natural gas production in recent years, methane emissions caused by energy activity have also been increasing greatly. It is estimated that gas produced in the coal-mining process (the main component of which is methane) in China increased from about 9.6 billion cubic metres in 2000 to about 12 billion cubic metres in 2004-an increase of 25 per cent. The large volume of coal-mine gas emissions is not only a waste of a valuable clean-energy resource, it has caused a rapid rise in methane gas emissions in China.

\section{Policy measures for environmental and energy development}

The Chinese Government attaches great importance to environmental protection, and strengthening environmental protection has become a basic national policy. Community awareness of environmental protection has generally improved. After the UN Conference on the Environment and Development in 1992, China formulated the China Agenda 21, and took comprehensive measures in the fields of law and economics and applied other means to strengthen environmental protection, achieving positive progress. The main components of China's energy policy are the reduction and effective management of environmental damage and pollution in the process of energy development and utilisation. 
Adhering to the strategy of economical, clean and safe development

China's energy development adheres to a policy of economical, clean and safe development and solves problems through development and reform. The government implemented the scientific development concept, adheres to the people-centred policy or strategy, changes the concept of development to give priority to human development, innovates the mode of development, improves the quality of growth and development. The government insists that energy development follow a path of high technology, low resource consumption, less environmental pollution, good economic returns and public safety in order to achieve comprehensive, coordinated and sustainable development.

China's energy development adheres to the basic principles of relying on the domestic market and opening up to the global economy, while ensuring a steady supply of energy and promoting global energy development along with the steady growth of domestic energy. China's energy development will bring more development opportunities to other countries in the world, open space for development in the international market and make a positive contribution to the security and stability of the world's energy supplies.

The basic contents of China's energy strategy are: to give priority to conservation; to rely on the domestic market; to attach importance to diversified development and environmental protection; to rely on science and technology; to strengthen international cooperation; and to make efforts to build a stable, economical, clean and safe energy-supply system to support sustainable economic and social development.

Giving priority to conservation. Resource conservation is a basic national policy in China, combining energy development and conservation. Priority is given to conservation, changing the mould of economic development, adjusting the industrial structure and encouraging research and development of energysaving technology. Priority is also given to the implementation of energy-saving products, improved energy management and energy-saving regulations and continuing improvements in energy efficiency.

Domestic supply. China will rely mainly on domestic energy supplies to meet its growing demand for energy by steadily improving the security and capacity of the domestic supply.

Diversified development. China will ensure a steady supply of energy through an orderly development of coal-generated electricity, accelerating the development of energy generation from oil and natural gas and encouraging the development of coal-bed methane production. It will also develop renewable 
energy sources such as hydro-power, and promote nuclear power development, the scientific development of alternative energy sources, the optimisation of energy structures and the implementation of multi-source energy.

Science and technology. China relies on the scientific and technological progress of energy development, while strengthening the capacity for independent innovation, improving the absorption of imported technology and re-innovation capabilities, achieving breakthroughs in the development of new energy technology, improving key technology and major equipment manufacturing, creating new methods of energy development and enhancing its development potential.

Environmental protection. China has a goal of building a resource-saving and environmentally friendly society. It actively promotes coordination between energy and environmental development, providing protection in the course of development and striving for sustainable development.

Mutually beneficial cooperation. China adheres to a principle of equality and mutual benefit. It has strengthened its energy cooperation with the International Energy Agency and the international community. It is working actively to improve the mechanisms for global cooperation to achieve and maintain international energy security and stability.

The seventeenth National People's Congress of the Communist Party of China, held in October 2007, identified a need to speed up the transformation of development, to quadruple per capita GDP from 2000 levels by 2020 by optimising the industrial structure, improving efficiency and lowering consumption while protecting the environment. Guidelines for the eleventh Five-Year Plan (2006-10) for National Economic and Social Development clearly propose that, by 2010 , the unit of energy use of GDP be reduced by 20 per cent from 2005 levels, and the emission of major pollutants should be reduced by 10 per cent.

To achieve the goals of economic and social development, the energy development objectives in the eleventh Five-Year Plan are: by the end of the FiveYear Plan, the energy supply will meet the basic needs of the national economy and social development; progress will be made in energy conservation; energy efficiency will be increased; industrial structures will be further optimised; technological progress, economic efficiency and market competitiveness will be enhanced significantly; macroeconomic regulation and control of the energy sector, market supervision, laws and regulations, and the emergency warning system adapted for the socialist market economy will gradually be perfected; and coordination between energy, economic, social and environmental development will be achieved. 


\section{Promotion of energy conservation}

China is a developing country with a large population and a relative shortage of resources. To achieve sustainable economic and social development, China must take the road of resource conservation. China planned and carried out energy-conservation efforts in the early 1980s, through the implementation of the policy of 'development and conservation simultaneously, conservation first', and, by the end of last century, it had achieved its goal of a doubling of economic and energy-consumption growth. To continue to promote energy conservation, the Chinese government has further proposed to adopt resource conservation as a basic national policy and it has issued a decision called 'work of the State Council on strengthening energy saving'. The Chinese government has always regarded energy conservation as the main component of macroregulation and control, to change the development mould and optimise the industrial structure. In the course of promoting energy savings, the government emphasises relying on restructuring, on scientific and technological progress, strengthening management and the legal system, deepening reforms and the participation of all citizens. The government formulated and implemented a 'special long-term plan for energy saving', set goals to reduce energy consumption during the eleventh Five-Year Plan and to implement energy-saving tasks in the provinces, autonomous regions and municipalities, as well as in key enterprises. China is improving its system of GDP and energy-consumption indicators, and energy consumption will be included in comprehensive evaluations and annual assessments of economic and social development. China will implement a bulletin of units of GDP energy consumption indexes, implement energy-saving responsibilities and accountability, construct an energy-efficient industrial system and promote fundamental changes in economic development. China's measures for full implementation of energy conservation measures include the following.

- Promote structural readjustment. For a long time, the main reason for China's low-energy efficiency has been that the mode of economic growth is extensive and high-energy industries takes too large a part. China insists on changing the mode of development, adjusting the industrial structure and the internal structure of industry as the strategic focus for energy conservation, and creating an economic development mould with low input, low consumption, low emissions and high efficiency. China will accelerate the optimisation and upgrading of the industrial structure, actively developing hi-tech and service industries, strictly limiting the development of high-energy and high water use industries, and eliminating backward production capacity. It will promote fundamental changes in economic development to speed up construction of an energyefficient industrial system. 
- Strengthen industrial energy conservation. Industry is the key area of China's energy consumption. China has decided to take the road to high scientific and technological content, good economic returns, low resource consumption, less environmental pollution, less human resources, faster development of high-tech industries, and the use of new and advanced applicable technologies to transform traditional industries and improve the overall level of industrial development. The government will focus on strengthening energy savings in the production of iron and steel, non-ferrous metals, coal, electricity, oil, petrochemicals, chemicals and construction materials. Energy savings will be implemented in 1,000 enterprises, with a focus on improving the management of energy savings in industrial enterprises that consume more than 10,000 tonnes of standard coal. Their product structure will be adjusted, accelerating technological transformation and improving their management, to reduce energy consumption. The government supports a number of major energy-saving demonstration projects, promoting industrial energy-efficiency levels and eliminating backward, high-energy products, as well as improving access to an efficient energy market.

- Implementation of energy-saving projects. China is implementing 10 key energy-saving projects, such as oil conservation, cogeneration and waste-heat utilisation; demonstration projects focused on energysaving construction; and encouraging the use of energy-saving products. The government will push for transformation of the existing energyconservation measures in construction, and promote the extensive use of new building materials. It will implement measures for conservation and alternative petroleum engineering and scientific development of alternative fuels. It will speed up the phasing out of old automobiles and ships, while actively developing public transport, restricting high fuel use vehicles and developing energy-saving and environmentally friendly vehicles. China will speed up the transformation of coal-fired industrial boilers and furnaces and regional cogeneration and wasteheat capture programs to increase the efficiency of energy use. The government will promote 'green' lighting projects and the use of efficient electrical appliances, high-efficiency coal stoves and energy-saving housing technology. In rural areas, old high-energy farm machinery and fishing boats will be phased out, and agricultural and rural energysaving measures will be promoted. The government and the community will play leading roles in energy conservation, monitoring and technical service systems. 
- Strengthening of energy management. The Chinese government has established a system of compulsory purchases of energy-saving products, and actively promotes the prioritised procurement of energy-conservation products (included water-related products). Government procurement will play an active role in guiding these policies, leading the society towards the use of energy-saving products. It will study and formulate fiscal and taxation policies to encourage energy conservation, implement preferential taxation policies for comprehensive utilisation of resources and establish a multi-channel energy financing mechanism. China will deepen the reform of energy prices, create a situation favourable to the energy price formation mechanism, implement fixed-asset investment project assessment and verification of energy-saving systems, and restrict the source of energy-consumption growth. The government will establish new mechanisms for energy-saving enterprises, labelling of energy-efficient products, and promote energy management and energysaving voluntary agreements. It will establish sound energy-saving laws and regulations, and step up law enforcement.

- Creating an energy-saving society. China publicises the importance of energy conservation in a variety of forms, continuously improving people's awareness of resource conservation. It promotes a culture of energy conservation, and works hard to create healthy, civilised and economical consumption patterns. Energy conservation is an integral part of basic education, vocational education, higher education and the technical training system. The government uses newspaper, radio, television and other media to promote knowledge of energy conservation; it holds an energy conservation publicity week, and mobilises the community to participate in establishing long-term energy-saving mechanisms throughout society.

Recent increases in energy demand have caused shortages and environmental problems. Recognising this, the Chinese government has made efforts to soften energy pressure, by introducing various policies and instructions. Energy has become one of the government's top concerns, especially since 2004. Recent energy policies include the Medium and Long-Term Energy Conservation Plan, the eleventh Five-Year Energy Plan, the Renewable Energy Law and the Fuel Efficiency Standard for Passenger Vehicles.

In 2005, the government set a target of reducing energy intensity by 20 per cent between 2005 and 2010. In order to reach the target, several programs were introduced, including 10 key energy-conservation projects (Table 15.4) and a monitoring program for 1,000 large energy users. The government regulates 
subsidies for renewable energy and a fuel tax and an energy tax are under discussion. The fuel tax will be implemented as part of the eleventh Five-Year Plan.

\section{Promoting coordination of energy development with environmental protection}

Climate change is a major global problem concerning the international community. It is not, however, just an environmental problem; ultimately, it is a development problem. The increasing development and utilisation of energy are the main causes of environmental pollution and climate change. All countries must find ways to correctly handle the relationship between the development and utilisation of energy, environmental protection and climate change.

China is a developing country in the early stages of industrialisation. China's carbon dioxide emissions from fossil fuels represent only 9.3 per cent of global

\section{Table 15.4 Energy-conservation projects approved by the Chinese government in 2005}

$\begin{array}{ll}\text { Program } & \text { Potential annual energy savings } \\ \text { Coal-fired industrial boiler conversion and } & 70 \text { Mtce (conversion) } \\ \text { increases in energy efficiency } & 35 \mathrm{Mtce} \text { (efficiency) } \\ \text { Heat-power cogeneration } & 5 \mathrm{Mtce} \\ \text { Residual heat and pressure usage } & 2.66 \mathrm{Mtce} \text { (steel industry) } \\ & 3 \mathrm{Mtce} \text { (cement industry) } \\ & 1.35 \mathrm{Mtce} \text { (coal-mining industry) } \\ \text { Oil conservation and substitution } & 35 \mathrm{Mt} \text { oil } \\ \text { Electrical machinery system energy } & 20 \text { billion kilowatt hours of electricity } \\ \text { conservation } & \\ \text { Energy system optimisation } & \text { Strive to achieve international benchmarks for } \\ & \text { energy efficiency in steel, petrochemical and } \\ & \text { chemical industries } \\ \text { Energy conservation in construction } & 50 \text { Mtce } \\ \text { Green lighting } & 29 \text { billion kilowatt hours of electricity } \\ \text { Energy conservation by government } & \text { Reduce energy consumption per capita and } \\ \text { organisations } & \text { per area of office space by } 20 \text { per cent } \\ & \text { between 2002 and } 2010 \\ \text { Energy conservation monitoring and } & \text { Implementation began in } 2006\end{array}$

technology services system construction

Source: National Development Research Commission. 
emissions, while its per capita carbon dioxide emissions put it at number 92 in the world; its unit of GDP carbon dioxide emission elasticity coefficient is also very small. As a responsible developing country, China has paid great attention to environmental protection and global climate change.

Treating environmental protection as a basic national policy, the Chinese government has signed the UN Framework Convention on Climate Change, has set up a national body to coordinate climate change measures, submitted a 'national communication of information on initial climate change', established the 'clean development mechanism management approach', developed a national program to cope with the effects of climate change, and has implemented a series of policies and measures related to environmental protection and climate change.

Goals for the period of the eleventh Five-Year Plan include containing the basic trend of ecological deterioration, reducing the total discharge of major pollutants by 10 per cent and effectively controlling greenhouse gas emissions.

China is actively adjusting its economic and energy structure, comprehensively promoting energy conservation, focusing on the prevention and control of environmental pollution, and effectively controlling pollution emissions, to promote the coordinated development of energy and protection of the environment.

\section{Climate change policies}

On 4 June 2007, the National Program for Climate Change (NPCC) was released-the first such program in the developing world. This document specified China's objectives, basic principles, key activities and projects, as well as policies and measures for the country as a response to climate change up to the year 2010. China will commit to completing all the tasks set out in NPCC, while constructing a resource-conservative and environmentally friendly society, building national capacity to mitigate and adapt to the effects of climate change, and contributing further to the protection and understanding of the global climate system.

The NPCC includes the following

- China's current and future efforts to deal with climate change

- the impacts and challenges of climate change in China

- guidelines, principles and objectives for China to respond to climate change

- policies and measures to address climate change

- China's position on key climate change issues and the need for international cooperation. 
In the short term, emission-mitigation policies will be implemented mainly through domestic energy-efficiency policies, renewable energy development, nuclear energy development, domestic sustainable development and energy security. In the long term, China's climate change policies will focus on further reductions in greenhouse gas emissions and policies such as a carbon tax, carbon pricing and so on. China will work together with other countries by joining an international emissions-reduction regime.

\section{Energy and emission scenarios}

According to the IPAC-Emission model, the primary energy demand in the baseline scenario will reach 4.5 billion tce in 2020 and 5.36 billion tce in 2030, with an annual growth rate of 3.6 per cent and an energy demand elasticity of 0.58 . Coal still accounts for the major part of China's energy consumption ( 2.2 billion tce in 2030, or 58 per cent of the total primary energy demand) and the need for natural gas will have a rapid increase, from 4 per cent to 12.3 per cent of the total energy demand from 2000 to 2030 (Table 15.4).

By assuming the adoption of energy and environmental policy measures, the primary energy demand in policy scenario results is described in table 5. Compared to the baseline scenario, there is 385 million tce energy demand by 2020, 4280 mtce in by 2030. There are 668 million tce reduction in 2020 and 1082 million tce in 2030. There are pressures to apply these policy options in order to reach the lower energy demand scenario, and these should be introduced at the earliest opportunity to take advantage of the long lifespan of energy technologies.

Energy demands in the baseline and policy scenarios are given in Table 15.6 and Table 15.7. Coal use in final energy keep going up due to energy intensive products' increase, such as steelmaking, and demand for space heating in the service and residential sector. Natural gas and electricity increased quickly with a share 9.2 per cent and 23.9 per cent in 2030, increasing from 2.7 per cent and 17 per cent in 2005. Industry is major sector for energy consumption. The increase for energy demand in industry up to 2020 continues due to increasing of energy intensive sector, but the growth rate is smaller than between 2000-2005.

$\mathrm{CO}_{2}$ emissions in 2020 and 2030 will reach 2.72 billion tons and 3.08 billion tons respectively. In the policy scenario, the $\mathrm{CO}_{2}$ emission will be lowered by 28.3 per cent during the same period.

A package of policy options could be adopted now to reduce the growth rate of energy demand. Policies that would help China move to a low-energy demand scenario include promotion of the penetration of high energy-efficiency technologies; fiscal energy and environment policies, vehicle fuel taxes; 

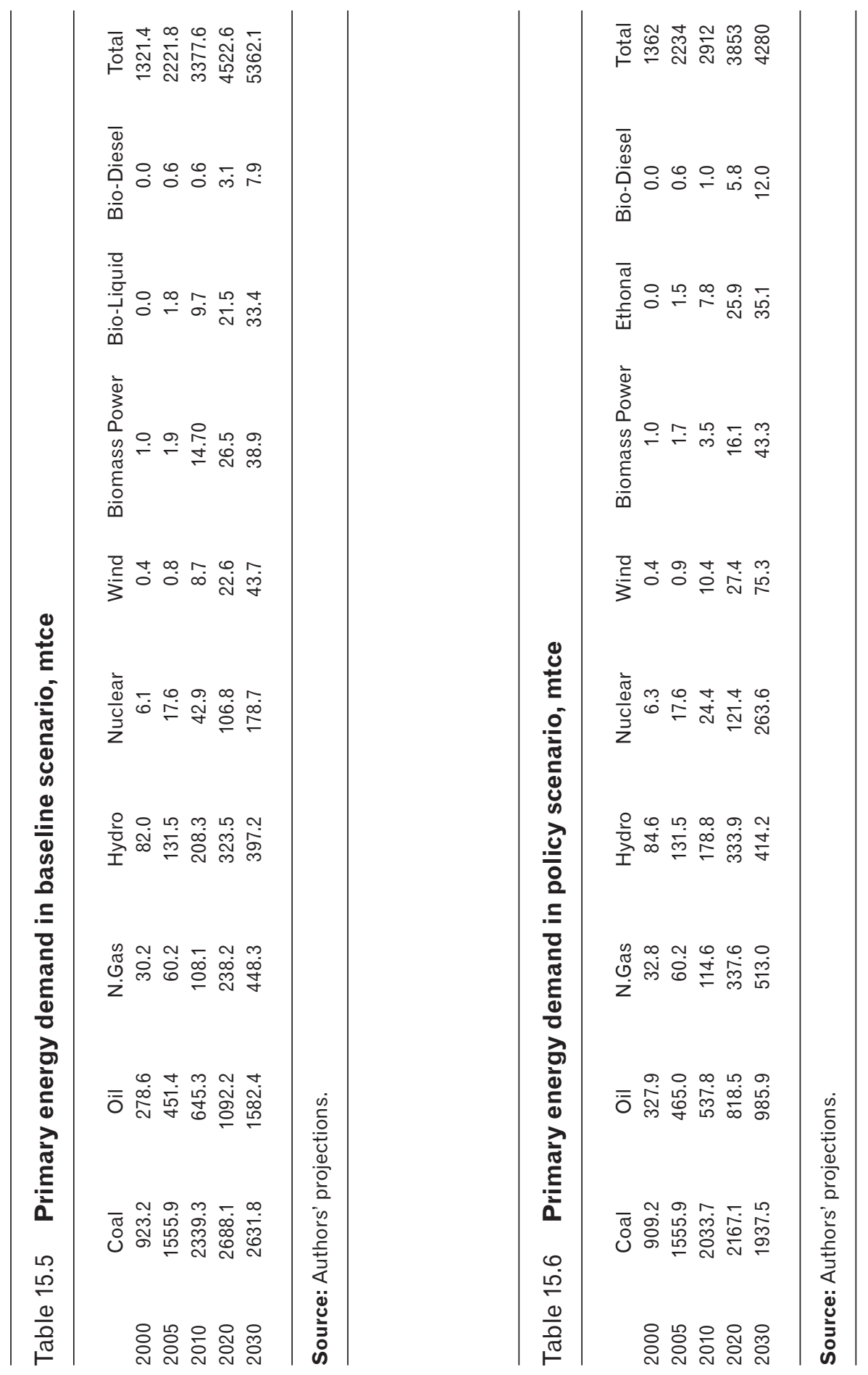
subsidies for renewable energy; emission taxes; resource taxes; promotion of public involvement (Table 15.8).

A package of policy options could be adopted now to reduce the growth rate of energy demand. Policies that would help China move to a low-energy demand scenario include promotion of the penetration of high energy-efficiency technologies; fiscal energy and environment policies, vehicle fuel taxes; subsidies for renewable energy; emission taxes; resource taxes; promotion of public involvement (Table 15.8).

\section{Conclusion}

China's energy demand is increasing rapidly as a result of rapid economic development. This trend is expected to continue for several decades.

The Chinese government has announced a package of energy-efficiency policies, renewable energy policies and environmental emission-control policies to reach its environmental targets. There is, however, still significant pressure to provide energy security and to control environmental pollution. The increase in energy demand means China will have to work hard to maintain its energy supply and energy imports. The increase in demand also increases the emissions of pollutants.

\section{Table 15.7 Final energy demand in baseline scenario}

\begin{tabular}{rrrcrrrrr}
\hline & Coal & Coke & Coal gas & \multicolumn{1}{c}{ Oil } & N.Gas & Heat & Electricity & Total \\
2000 & 421.6 & 81.2 & 12.8 & 265.2 & 22.2 & 59.5 & 148.7 & 1011.2 \\
2005 & 670.5 & 196.8 & 26.7 & 405.5 & 44.9 & 90.5 & 269.8 & 1704.7 \\
2010 & 934.1 & 224.8 & 31.2 & 614.3 & 77.8 & 158.8 & 407.3 & 2448.3 \\
2020 & 1087.6 & 211.3 & 33.0 & 1039.2 & 145.9 & 273.1 & 566.4 & 3356.6 \\
2030 & 1136.6 & 164.7 & 23.8 & 1504.5 & 246.0 & 400.3 & 720.4 & 4196.3 \\
\hline
\end{tabular}

Source: Authors' projections.

\section{Table 15.8 Final energy demand in policy scenario}

\begin{tabular}{rrrcrrrrr}
\hline & Coal & Coke & Coal gas & Oil & N.Gas & Heat & Electricity & Total \\
2000 & 394.8 & 82.9 & 12.8 & 271.3 & 22.2 & 54.0 & 153.3 & 991.4 \\
2005 & 616.7 & 192.1 & 26.7 & 405.1 & 45.0 & 83.4 & 280.2 & 1649.2 \\
2010 & 684.8 & 212.8 & 26.3 & 501.6 & 67.0 & 110.7 & 411.2 & 2014.4 \\
2020 & 801.9 & 187.8 & 29.7 & 823.7 & 178.0 & 174.4 & 588.1 & 2783.6 \\
2030 & 757.1 & 125.0 & 18.9 & 951.4 & 283.1 & 202.9 & 735.4 & 3073.8 \\
\hline
\end{tabular}

Source: Authors' projections. 


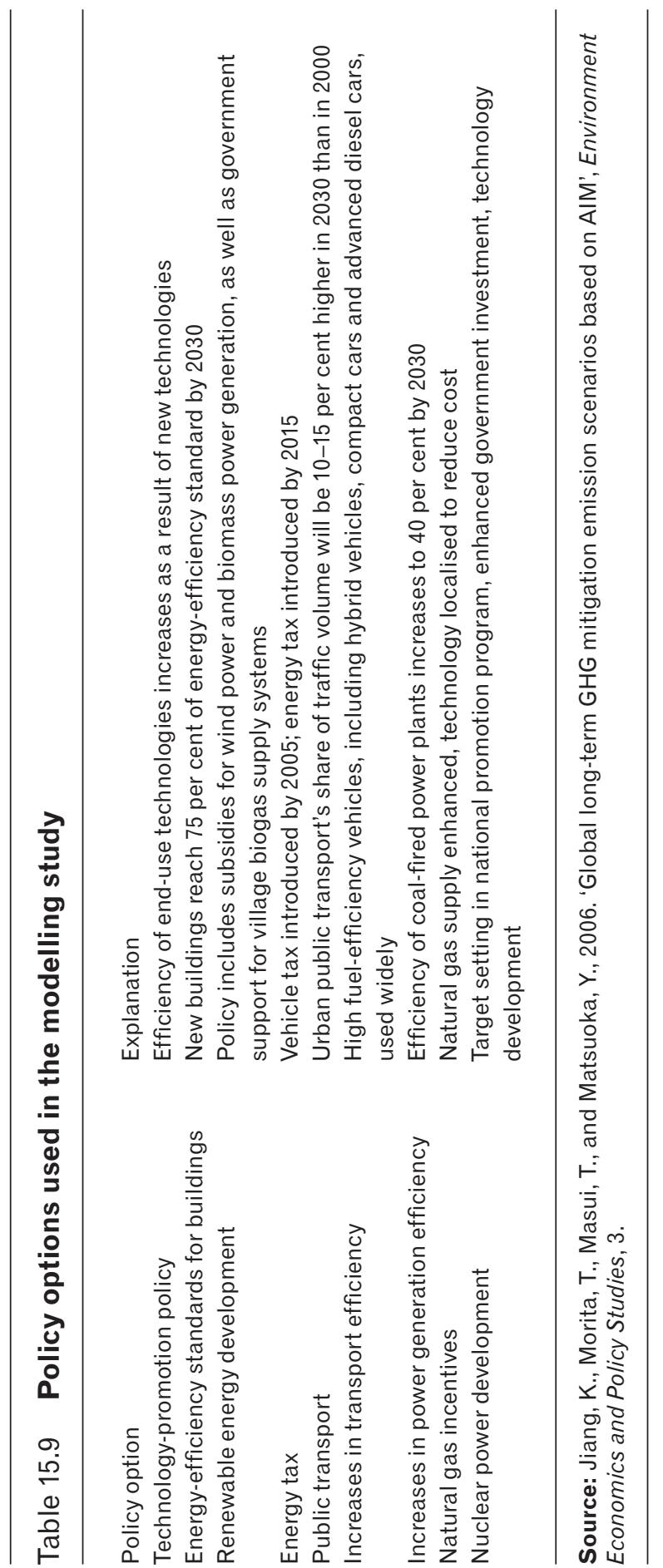


China is paying great attention to climate change issues. Domestic action on energy efficiency and renewable energies has contributed to China's mitigation of greenhouse gas emissions.

Analysis of various scenarios for the future shows that such a high level of energy demand and imports will put heavy pressure on China's energy-supply system. A well-designed strategy for the energy system and energy-industry development should therefore be prepared. That strategy should consider the following options.

- Because technological progress is key to reducing energy demand and ensuring a clean future, much more emphasis should be placed on new-generation technologies. In the simulations, technological progress contributes much of the energy savings while having no negative effects on public welfare.

- Export taxes are imposed on energy-intensive products. Energy, resource and similar taxes have significant effects on energy saving and optimisation of the economic structure. They should be given much more attention.

- Like other developing countries with high levels of energy imports, China should establish an energy security system. The size of strategic storage should be determined based on a global oil market situation.

- If there is no strong control of emissions, pollution will increase quickly in the short term. In the longer term, some pollutant emissions could be controlled by implementing various measures adopted by the government.

- Clean-coal technology should be emphasised to mitigate emissions from coal combustion. Only a few countries in the world are using coal on a large scale; development of clean-coal technologies therefore depends on them. China is the largest user of coal in the world, and its use of coal will increase in the future (by 2020, China could account for more than 40 per cent of global coal consumption). Therefore, clean-coal technology is crucial. China should have a clear development plan to promote cleancoal technology, working closely with other countries to develop a new generation of clean-coal technologies.

Because of its low production costs, China is likely to become a major manufacturing centre, producing energy and resource-intensive products. China must ensure it does not become excessively reliant on raw materials, the extraction of which causes damage to the environment. External costs should be included in production costs. Planning for energy and resource-intensive products should include measures to avoid environmental and economic damage. 


\section{References}

Asian Integrated Model(AIM) Project Team, 1996. A guide to the AIM/end-use model, AIM Interim Paper, IP-95-05, Tsukuba.

China Environment Year Book Editing Committee, 2007. China Environment Year Book, Beijing.

China Statistics Publishing House, 2007. China Energy Statistic Yearbook, 2007, China Statistics Publishing House, Beijing.

Edmonds, J. and Reilly, J., 1983. 'A long-term global energy-economic model of carbon dioxide release from fossil fuel use', Energy Economics, 5:75-88.

Hu, X. and Jiang, K., 2001. Greenhouse Gas Mitigation Technology Assessment [in Chinese], China Environment Science Publishing House, Beijing.

$\mathrm{Hu}, \mathrm{X}$. , Jiang, K. and Liu, J., 1996. Application of AlM/emission model in China and preliminary analysis on simulated results, AIM Interim Paper, IP-96-02, Tsukuba.

Intergovernmental Panel on Climate Change (IPCC), 2007a. Climate Change 2007: Mitigation, Working Group III, Cambridge University Press, Cambridge.

- - 2001b. IPCC Special Report on Emission Scenario, Cambridge University Press, Cambridge.

- - 2007. Synthesis Report of TAR, Cambridge University Press, Cambridge. Jiang, K. and Xiulian, H., 2006. 'Energy demand and emission in 2030 in China: scenarios and policy options', Environment Economics and Policy Studies, 7(3):233-50.

Jiang, K., Hu, X., Matsuoka, Y. and Morita, T., 1998. 'Energy technology changes and $\mathrm{CO}_{2}$ emission scenarios in China', Environment Economics and Policy Studies, 1:141-60.

Jiang, K., Masui, T., Morita, T. and Matsuoka, Y., 2000. 'Long-term GHG emission scenarios of Asia Pacific and the world', Technological Forecasting and Social Change, 61:2-3.

Jiang, K., Morita, T., Masui, T., and Matsuoka, Y., 1999. 'Long-term emission scenarios for China', Environment Economics and Policy Studies, 2:267-87.

- - 2006. 'Global long-term GHG mitigation emission scenarios based on AIM', Environment Economics and Policy Studies, 3.

Li, J., 2007. Renewable Energy Development in 2006, Energy Research Institute, Beijing.

Liu, J., Ma, F. and Fang, L., 2002. China Sustainable Development Strategy [in Chinese], China Agriculture Publishing House, Beijing. 
Lu, Z., Zhao, Y. and Shen, Z., 2003. Can China Become a Global Factory? in Chinese], Economic Management Publishing House, Beijing.

Power Industry Information, 2005. China Power, 38:3.

Qu, K., 2003. Energy, Environment Sustainable Development Study, China Environment Science Publishing House, Beijing.

State Statistical Bureau, 2007. China Energy Year Book 2007, China Statistical Publishing House, Beijing.

- - 2005. China Year Book 2005, China Statistical Publishing House, Beijing.

Zheng Y., Zhang, X., and Xu, S., 2004. China Environment and Development Review, Social Science Documentation Publishing House, Beijing. 